\title{
Ultrasensitive detection of genomic DNA from apple leaf tissues, using surface-enhanced Raman scattering
}

\author{
Cristina M. Muntean ${ }^{\mathrm{a}, *}$, Nicolae Leopold ${ }^{\mathrm{b}}$, Adela Halmagyi ${ }^{\mathrm{c}}$ and Sergiu Valimareanu $^{\mathrm{c}}$ \\ ${ }^{a}$ National Institute for Research \& Development of Isotopic and Molecular Technologies, Cluj-Napoca, \\ Romania \\ ${ }^{\mathrm{b}}$ Faculty of Physics, Babeş-Bolyai University, Cluj-Napoca, Romania \\ ${ }^{\mathrm{c}}$ Institute of Biological Research, Cluj-Napoca, Romania
}

\begin{abstract}
Ultrasensitive detection of nucleic acids is demonstrated through exploiting the effect of surface-enhanced Raman scattering (SERS). In this work the SERS spectra of eight genomic DNAs from leaves of apple trees grown in the field (Malus domestica Borkh., Fam. Rosaceae, cultivars. Florina, Idared, Rebra, Goldrush, Romus 3, Romus 4 and the rootstocks M9 and M26) have been analyzed in the wavenumber range $200-1800 \mathrm{~cm}^{-1}$. SERS signatures, spectroscopic band assignments and structural interpretations of these plant genomic DNAs are reported. SERS spectra of nucleic acids are compared here with caution, because these signals are time-dependent and are strongly influenced by DNA amount in the measured sample volume. Similarities of the SERS spectra of genomic DNAs extracted from apple leaves of Goldrush, Rebra and Florina cultivars, respectively, have been detected. Besides, the SERS spectra, corresponding to DNA from M9, Romus 4 and M26, leaves, respectively, show similar features and well resolved bands. Based on this work, specific plant DNA-ligand interactions or DNA structural changes induced by plant stress conditions associated with their natural environment, might be further investigated using surface-enhanced Raman spectroscopy.
\end{abstract}

Keywords: Surface-enhanced Raman scattering (SERS), genomic DNA, apple leaves

\section{Introduction}

Sensitive and detailed molecular structural information plays an increasing role in molecular biophysics and molecular medicine [16]. Therefore, vibrational spectroscopic techniques, such as Raman scattering, which provide high structural information content are of growing interest in biophysical and biomedical research [16]. However, normal Raman spectroscopy has an extremely small scattering cross section, which limits its use as a low-level bioanalytical sensor [32,38].

Recent advances in the field of surface-enhanced Raman spectroscopy have demonstrated the utility of this technology in diverse research disciplines, ranging from surface chemistry and electrochemistry to the development of protein/nucleic acid sensor technologies [14].

Any molecule located within several nanometers to the metal nanoparticle surface can contribute to the measured SERS vibrational spectrum, leading to complex spectra that can be difficult to analize and

\footnotetext{
${ }^{*}$ Corresponding author: Cristina M. Muntean, National Institute for Research \& Development of Isotopic and Molecular Technologies, P.O. 5, Box 700, R-400293 Cluj-Napoca, Romania. Tel.: +40 264 584037; E-mail: cmuntean@itim-cj.ro.
} 
interpret [36]. The main limitation of SERS spectroscopy is that it is a surface based technique, requiring the use of an appropriate surface to provide the desired enhancement [11].

To describe the overall SERS effect, long-range electromagnetic effect (EM) and short-range chemical effect (CM) [32] have been generally accepted as two separated mechanisms. Strongly increased Raman signals can be obtained due to resonances between optical fields and the collective oscillations of the free electrons in the metal [16]. The CM mechanism stems from the interaction between adsorbed molecules and the metal surface, such as charge transfer (CT) interaction of adsorbed molecules with the metal [20,32] and references therein.

The average surface enhancement factors of noble metals range from $10^{3}$ to $10^{6}$ [37], but have also been reported to be as high as $10^{14}-10^{15}$ for single molecule detection [14] and references therein.

Particularly, DNA SERS and SERRS (surface enhanced resonance Raman scattering) signatures might provide an objective evaluation of genetic identity of plants based on species, cultivars, or geographic origin [20].

As far as plant DNA is concerned, a previous FT-Raman study of genomic DNA from leaf tissues has been conducted by us [19]. Also, we have repeated FT-Raman experiments for other DNA molecules extracted from plant tissues, but we have observed no FT-Raman signal above the reference buffer one (data not shown). Thus, applying SERS spectroscopy for the investigation of low level DNA isolated from leaves became a demand.

In this work, the SERS spectra of eight genomic DNAs from leaves sampled from apple trees grown in the field (Malus domestica Borkh., Fam. Rosaceae, cvs. Florina, Idared, Rebra, Goldrush, Romus 3, Romus 4 and the rootstocks M9 and M26) have been studied between $200-1800 \mathrm{~cm}^{-1}$. SERS signatures, spectroscopic band assignments and structural interpretations for these plant genomic DNAs are reported.

In biochemical fields, plant DNA might be used to explore the interaction between DNA and small molecules, which is important in connection with probing the accurate local structure of DNA and with understanding the natural DNA-mediated biological mechanisms [32].

\section{Materials and methods}

\subsection{DNA extraction protocol}

Leaves sampled from apple trees grown in the field (Malus domestica Borkh., Fam. Rosaceae, cvs. Florina, Idared, Rebra, Goldrush, Romus 3, Romus 4 and the rootstocks M9 and M26) were selected for our studies.

Genomic DNA was isolated from leaves of the above mentioned cultivars and rootstocks [8]. DNA extraction protocol is presented elsewhere [20].

\subsection{Surface-enhanced Raman spectroscopy}

\subsubsection{Chemicals}

Analytical reagent grade, characterized all chemicals used in this work. The silver colloidal SERS substrate was prepared by reducing $\mathrm{Ag}^{+}$with hydroxylamine [17]. Metallic nanoparticles with an estimated size of $34 \mathrm{~nm}$ have been obtained [17].

Method used for silver colloid preparation is described elsewhere [20]. 
Table 1

DNA amount in the measured samples volume

\begin{tabular}{lc}
\hline Apple leaves & DNA amount $(\mathrm{ng} / \mu \mathrm{l})$ \\
\hline Goldrush & 0.1021 \\
Rebra & 0.0881 \\
Romus 3 & 0.131 \\
Idared & 0.122 \\
M9 & 0.122 \\
Romus 4 & 0.088 \\
M26 & 0.070 \\
Florina & 0.070 \\
\hline
\end{tabular}

Each sample was prepared by adding $500 \mu \mathrm{l}$ silver colloid into a $1 \mathrm{ml}$ glass cuvette. Certain DNA solution quantities were added to the silver colloids. The final DNA amount in the measured samples volume is shown in Table 1. Different DNA concentrations have been analyzed by us, as compared with our previous work [20].

We did not observe any change of colour in the DNA samples prepared for SERS study, this being a proof that the silver remains colloidal and is not aggregated upon interaction with genomic nucleic acids [20].

For several samples, SERS spectra of colloidal suspensions with different DNA amount were registered. The most accurate SERS spectrum, showing well resolved bands, is presented in Fig. 1 for each DNA type sample.

\subsubsection{Instrumentation}

A DeltaNu Advantage spectrometer (DeltaNu, Laramie, WY, USA) equipped with a doubled frequency Nd:YAG laser emitting at $532 \mathrm{~nm}$ and $45 \mathrm{~mW}$ laser power, was used for recording the SERS spectra.

These spectra were obtained by averaging 5 recordings, each of $10 \mathrm{~s}$ exposure.

\section{Results and discussion}

SERS spectral profiles in the region $200-1800 \mathrm{~cm}^{-1}$ of eight genomic DNAs, are presented in Fig. 1. Nucleic acids were extracted from leaves sampled from apple trees grown in the field (Malus domestica Borkh., Fam. Rosaceae, cvs. Florina, Idared, Rebra, Goldrush, Romus 3, Romus 4 and the rootstocks M9 and M26, respectively). Labels indicate wavenumber values for the more prominent bands in each spectrum $\left(\mathrm{cm}^{-1}\right.$ units).

Table 2 presents a detailed comparative analysis of the surface-enhanced Raman scattering spectra of the eight genomic DNAs. Proposed SERS band assignments found in the literature for similar compounds are also included. In some cases, assignments are described in terms of a specific DNA atom or functional group, which makes the related Raman band very useful for recognition of specific DNAligand interactions $[19,28]$.

The SERS spectrum originates from molecules that are in close proximity to the enhanced electromagnetic field at the nanoparticle surface [36].

A strong dependence of the SERS spectra on genomic DNA amount in the sample volume has been observed by us. In this regard, Fig. 2 presents the SERS spectra of genomic DNA extracted from apple leaves of Goldrush cultivar at two different concentrations. Sample corresponding to spectrum B is 


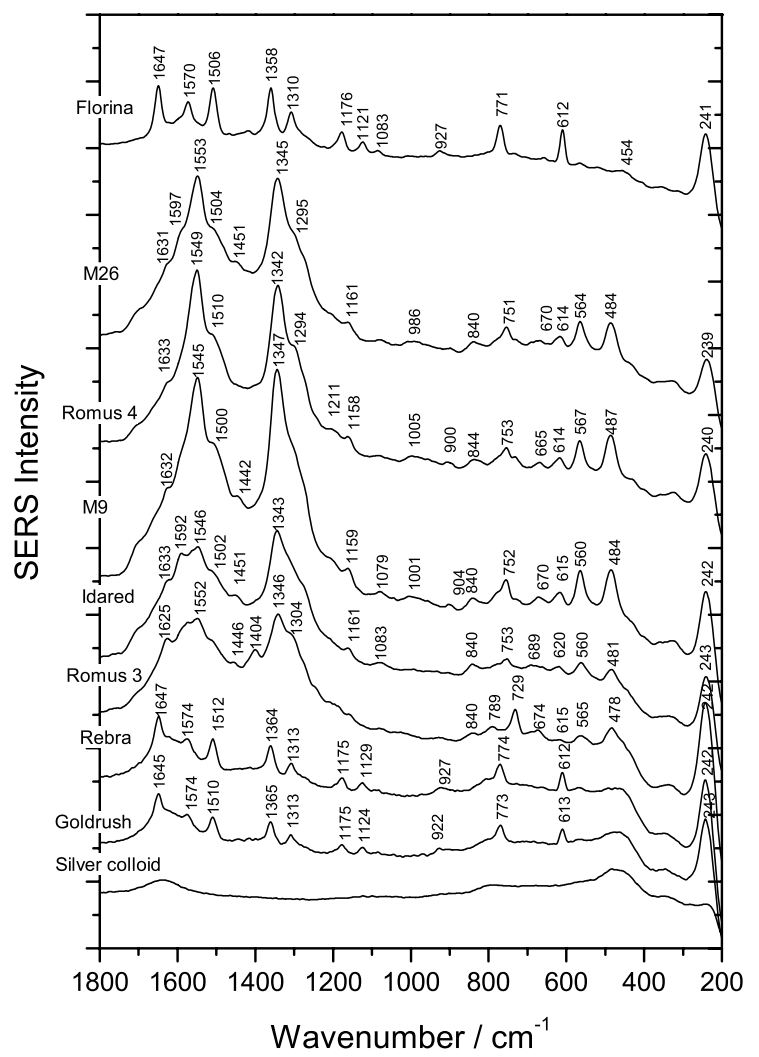

Fig. 1. SERS spectra of genomic DNAs from apple leaves sampled from the trees (cultivars and rootstocks), as labeled in the figure. Bottom, SERS spectrum of the silver colloid (blank spectrum). Spectra are presented at the same intensity scale expansion.

diluted $50 \times$ as compared with the sample corresponding to spectrum A. Thus, enhancement patterns detected in the SERS spectra are not only related to the type of DNA under consideration, but also to the packing density at the silver nanoparticles surfaces. Previously, a correlation of molecular orientation and packing density in a dsDNA self-assembled monolayer was observed with surface-enhanced Raman spectroscopy [2]. Other authors have also found a concentration dependence of the SERS spectra of DNA molecules [12].

Besides, the well-known SERS saturation effect that occurs when too much material is on the substrate, might explain some results on DNA samples at high biomolecular concentration.

Intensity and wavenumber changes of the SERS bands of the DNA-silver colloid system with time were also observed. Figure 3 presents the SERS spectra of genomic DNA extracted from apple leaf tissues of Florina cultivar. Spectrum B was registered on the same sample as spectrum A, but one day after. Such effects have also been found by Ke et al. [15]. After several hours of interaction between the Ag colloid and the DNA, more accurate spectra were observed, with well defined SERS bands and a better signal to noise ratio.

Figure 1 shows a typical blank SERS spectrum of the silver colloid, obtained with our setup. It can be observed that the water band at $\sim 1650 \mathrm{~cm}^{-1}$ and the glass cuvette fluorescence band in the 400 $800 \mathrm{~cm}^{-1}$ region, have no significant contribution in the DNA SERS spectra. 
Table 2

SERS wavenumbers $\left(\mathrm{cm}^{-1}\right)$ and tentative assignments of genomic DNA from leaves of different apple cultivars and rootstocks, sampled from apple trees grown in the field $[15,19,22,32,37,38]$

\begin{tabular}{|c|c|c|c|c|c|c|c|c|}
\hline Goldrush & Rebra & Romus 3 & Idared & M9 & Romus 4 & M26 & Florina & Tentative assignment $^{\mathrm{a}}$ \\
\hline & & 674 & 689 & 670 & 665 & 670 & & $\mathrm{dG}$ \\
\hline & & 729 & & & & & & $\mathrm{dA}$ \\
\hline & & & 753 & 752 & 753 & 751 & & $\mathrm{dT}$ \\
\hline \multirow[t]{4}{*}{773} & 774 & & & & & & 771 & $\mathrm{dC}$ \\
\hline & & 789 & & & & & & $\mathrm{dC}, \mathrm{bk}^{\mathrm{c}}$ \\
\hline & & 840 & 840 & 840 & 844 & 840 & & $\nu(\mathrm{O}-\mathrm{P}-\mathrm{O}), \mathrm{B}$-type \\
\hline & & & & 904 & 900 & & & deoxyribose \\
\hline \multirow[t]{3}{*}{922} & 927 & & & & & & 927 & deoxyribose \\
\hline & & & & 1001 & 1005 & 986 & & $\nu(\mathrm{C}=\mathrm{C})_{\mathrm{sym}}($ ring $)$, deoxyribose \\
\hline & & & 1083 & 1079 & & & 1083 & $\mathrm{PO}_{2}^{-}$sym. stretch, bk ${ }^{\mathrm{c}}$ \\
\hline \multirow[t]{2}{*}{1124} & 1129 & & & & & & 1121 & $\mathrm{dA}$ \\
\hline & & & 1161 & 1159 & 1158 & 1161 & & deoxyribose-phosphate \\
\hline \multirow[t]{2}{*}{1175} & 1175 & & & & & & 1176 & ring vibrations of $\mathrm{dC}$, \\
\hline & & & & & $1211 \mathrm{sh}^{\mathrm{b}}$ & & & $\mathrm{dC}, \mathrm{dT}$ \\
\hline \multirow[t]{2}{*}{1313} & 1313 & $1304 \mathrm{sh}^{\mathrm{b}}$ & & & $1294 \mathrm{sh}^{\mathrm{b}}$ & $1295 \mathrm{sh}^{\mathrm{b}}$ & 1310 & $\mathrm{dA}$ \\
\hline & & 1346 & 1343 & 1347 & 1342 & 1345 & & $\mathrm{dG}, \mathrm{dA}$ \\
\hline \multirow[t]{3}{*}{1365} & 1364 & & & & & & 1358 & $\mathrm{dT}, \mathrm{dA}$ \\
\hline & & 1404 & & & & & & $\mathrm{dT}, \mathrm{dA}, \mathrm{dG}$ \\
\hline & & $1446 \mathrm{sh}^{\mathrm{b}}$ & 1451 & 1442 & & 1451 & & deoxyribose, $\mathrm{dCH}_{2}$ \\
\hline \multirow[t]{2}{*}{1510} & 1512 & & $1502 \mathrm{sh}^{\mathrm{b}}$ & $1500 \mathrm{sh}^{\mathrm{b}}$ & $1510 \mathrm{sh}^{\mathrm{b}}$ & $1504 \mathrm{sh}^{\mathrm{b}}$ & 1506 & $\mathrm{dA}$ \\
\hline & & 1552 & 1546 & 1545 & 1549 & 1553 & & $\mathrm{dG}, \mathrm{dA}$ \\
\hline 1574 & 1574 & & 1592 & & & & 1570 & $\mathrm{dG}, \mathrm{dA}$ \\
\hline 1645 & 1647 & 1625 & $1633 \mathrm{sh}^{\mathrm{b}}$ & $1632 \mathrm{sh}^{\mathrm{b}}$ & $1633 \mathrm{sh}^{\mathrm{b}}$ & $1631 \mathrm{sh}^{\mathrm{b}}$ & 1647 & $\mathrm{dT}(\mathrm{C}=\mathrm{O}), \delta\left(\mathrm{H}_{2} \mathrm{O}\right)$ \\
\hline
\end{tabular}

Notes: ${ }^{\mathrm{a}}$ Abbreviations: dA - deoxyadenosine; $\mathrm{dG}$ - deoxyguanosine; $\mathrm{dC}$ - deoxycytidine; $\mathrm{dT}$ - thymidine; ${ }^{\mathrm{b}} \mathrm{sh}-\mathrm{shoulder}^{\mathrm{c}} \mathrm{bk}-$ backbone.

Further, in the SERS spectra of DNA presented in Fig. 1, a strong intensity band is to be observed around $241 \mathrm{~cm}^{-1}$. This vibration might be assigned to $\nu(\mathrm{Ag}-\mathrm{N})$ or to metal-oxygen single bonds [1] Metal-nitrogen wavenumbers, $\nu(\mathrm{M}-\mathrm{N})$, of single bonds were found to appear in the range between $500-200 \mathrm{~cm}^{-1}$ [1]. Stereochemistry and coordination number, nature of the metal and its oxidation state are factors influencing the position of the wavenumber. The nature and the structure of the ligand containing the nitrogen atom to which the metal is linked, plays also an important role and influences the wavenumber [1].

The spectral interval $600-800 \mathrm{~cm}^{-1}$ contains Raman bands that originate from vibrations involving concerted ring stretching motions (ring breathing) of purine or pyrimidine residues, often in combination with stretching of the glycosidic bond and possibly also stretching of bonds within the linked deoxyribose ring [6,22]. These bands thus combine the relatively high Raman intensity typical for base residue vibrations with the sensitivity in wavenumber value expected from changes in glycosyl torsion angle and/or deoxyribose ring pucker ( $\mathrm{C} 2^{\prime}$-endo vs. $\mathrm{C} 3^{\prime}$-endo) $[6,22]$.

Bands appearing in the SERS spectra of genomic DNAs from leaf tissues between 665 and $674 \mathrm{~cm}^{-1}$ (see Fig. 1) are supposed to be the diagnostic of the $\mathrm{C} 2^{\prime}$-endo-syn conformation of dG [30]. Band near $689 \mathrm{~cm}^{-1}$, in the case of DNA extracted from Idared cultivar, is a diagnostic of $\mathrm{C}^{2}$-endo-anti conformation of dG. However, it is possible that the wavenumber shifts observed for these peaks in the 


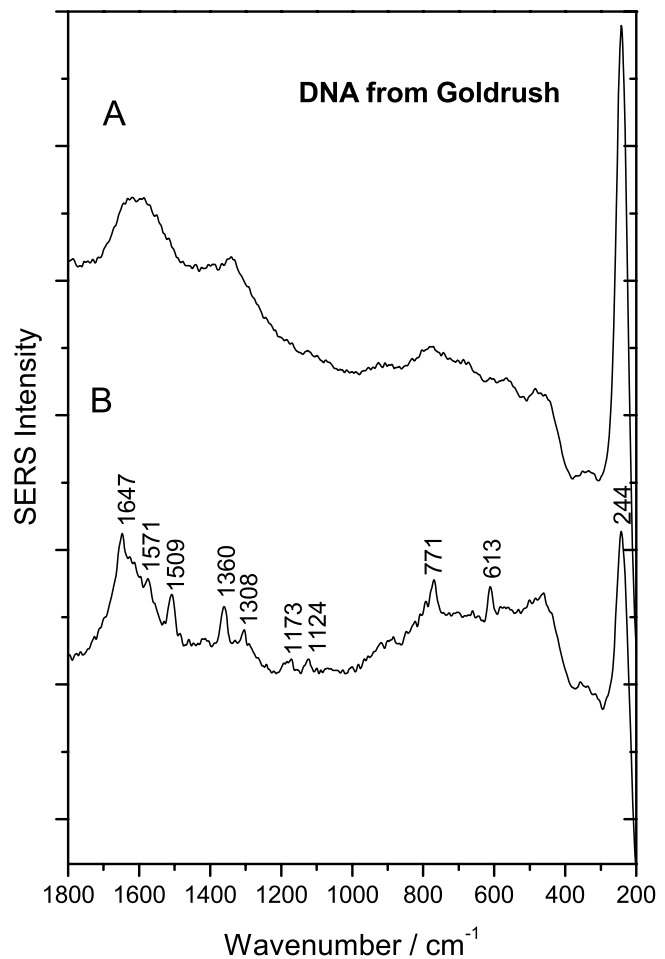

Fig. 2. SERS spectra of genomic DNA extracted from apple leaves of Goldrush cultivar. Sample corresponding to spectrum B is diluted $50 \times$ as compared with the sample corresponding to spectrum A. Spectra are presented at the same intensity scale expansion.

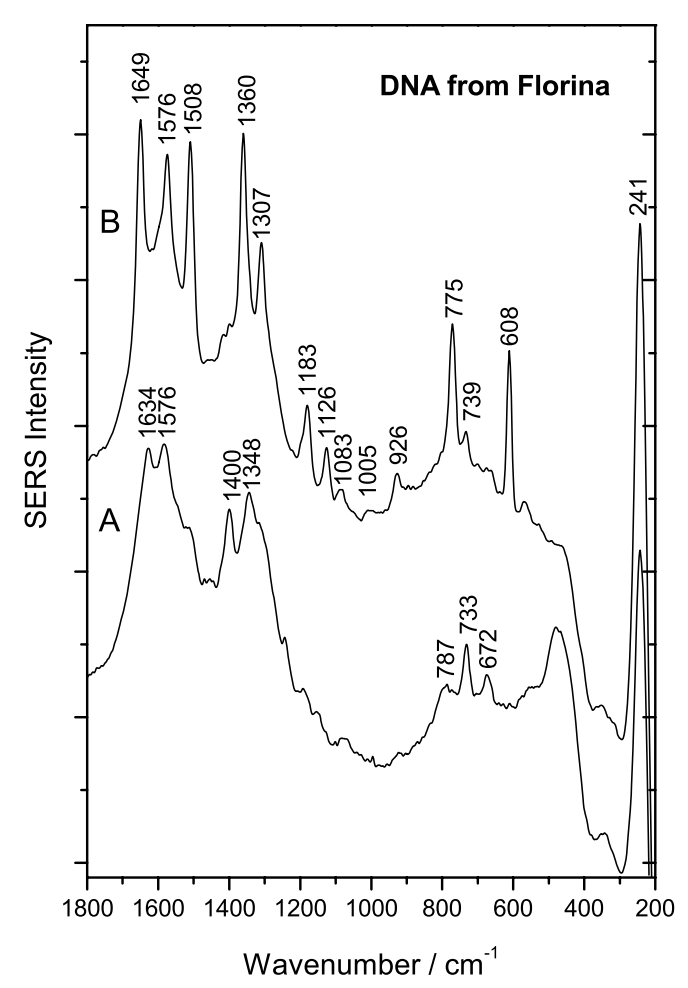

Fig. 3. SERS spectra of genomic DNA extracted from apple leaf tissues of Florina cultivar. Spectrum B was registered on the same sample as spectrum A, but one day after. Spectra are presented at the same intensity scale expansion.

SERS spectra as compared with previous normal Raman literature, might be due to the interaction of the metallic substrate with DNA molecules [32]. A partial conformational change upon adsorption of the biomolecule to the silver surface might be considered to take place.

A band noticed at $729 \mathrm{~cm}^{-1}$ in the case of DNA from Romus 3 cultivar, might be due to the $\mathrm{C} 2^{\prime}$-endoanti nucleoside conformers of dA [7,21,22,27,33] (see Table 2).

The dT conformation marker was observed near $752 \mathrm{~cm}^{-1}$ for DNA extracted from tissues of M9 leaves. The same SERS band shifted to $753 \mathrm{~cm}^{-1}$ in the case of DNA extracted from Idared and Romus 4 leaves, respectively, and to $751 \mathrm{~cm}^{-1}$ for leaf tissues of M26 rootstock.

A strong band was found at $773 \mathrm{~cm}^{-1}$ for genomic DNA extracted from Goldrush leaves (Fig. 1). This band, originating from $\mathrm{C} 2^{\prime}$-endo-anti nucleoside conformers of $\mathrm{dC}$, appeared at $774 \mathrm{~cm}^{-1}$ in the SERS spectrum of DNA from Rebra cultivar and at $771 \mathrm{~cm}^{-1}$ for genomic DNA extracted from cv. Florina leaves. In the case of the band near $789 \mathrm{~cm}^{-1}$ in the SERS spectrum of DNA from cv. Romus 3 leaves, it is supposed that the $\mathrm{dC}$ ring breathing mode at $783 \mathrm{~cm}^{-1}$ might overlap with the backbone mode near $792 \mathrm{~cm}^{-1}[37]$.

The marker band of B-form DNA backbone and C2'-endo sugar conformations [27,30] is centered around $835 \mathrm{~cm}^{-1}[23,27,29,30]$ in the normal Raman spectrum of calf thymus DNA. This medium intensity band is due to a complex vibrational mode involving the deoxyribose-linked phosphodiester network $\left(5^{\prime} \mathrm{C}-\mathrm{O}-\mathrm{P}-\mathrm{O}-\mathrm{C} 3^{\prime}\right)$ of B-DNA [6,22]. 
In our SERS spectra a weak band appeared at $840 \mathrm{~cm}^{-1}$ for DNAs extracted from Romus 3, and Idared cultivars, and M9, M26 rootstocks leaves, respectively. The same marker band, was observed at $844 \mathrm{~cm}^{-1}$ for DNA sample purified from leaves of Romus 4 cultivar.

The band near $904 \mathrm{~cm}^{-1}$, which was observed in the spectrum of DNA from M9 leaf tissues, is assigned to deoxyribose [10]. This band was detected at $900 \mathrm{~cm}^{-1}$ for genomic DNA extracted from leaves of Romus 4 cultivar.

The sugar residues of DNA are expected to be the major contributors to the weak SERS band observed near $927 \mathrm{~cm}^{-1}$, in the case of DNAs extracted from cvs. Rebra and Florina leaves, respectively [19] and references therein. This band, assigned to a vibration localized in the deoxyribose moiety, was detected at $922 \mathrm{~cm}^{-1}$ in the case of genomic DNA extracted from leaves of cv. Goldrush (Fig. 1).

A weak band near $1001 \mathrm{~cm}^{-1}$, in the SERS spectrum of genomic DNA extracted from M9 leaves is observed at $1005 \mathrm{~cm}^{-1}$ for cv. Romus 4 DNA, and at $986 \mathrm{~cm}^{-1}$ in the SERS spectrum of the DNA extracted from rootstock $\mathrm{M} 26$, respectively, being probably due to a $\nu(\mathrm{C}=\mathrm{C})_{\mathrm{sym}}$ (ring) vibration [38]. A sharp SERS peak near $998 \mathrm{~cm}^{-1}$, attributed to the deoxyribose vibration, was observed by other authors for single-stranded oligonucleotides [26].

A band is observed at $1083 \mathrm{~cm}^{-1}$ in the SERS spectra of genomic DNAs extracted from leaves of Idared and Florina cultivars, respectively. This mode is due to the localized symmetric stretching vibration of the phosphodioxy $\left(\mathrm{PO}_{2}{ }^{-}\right)$moiety, being independent of the base composition and sequence $[4,9,13,18,23-25,34,35,37]$. Also, this marker band, which has a higher intensity in the normal Raman spectrum of DNA, was found at $1079 \mathrm{~cm}^{-1}$ in our SERS spectrum of DNA extracted from rootstock M9 leaves (Fig. 1).

Raman spectrum of DNA contains many overlapping bands in the region $1100-1600 \mathrm{~cm}^{-1}$, which originate primarily from in-plane vibrations of base residues [6,19] and references therein. Previous studies [6] and references therein showed that these bands cannot be assigned unambiguously because of the peaks overlap and also because the intensity of the bands in this spectral range is in general sensitive to the base-stacking interactions (Raman hypochromism) [19].

The $1124 \mathrm{~cm}^{-1}$ band in the SERS spectrum of DNA from cv. Goldrush, might be attributed to the ring vibration of adenine [5,19]. This vibration was observed at $1129 \mathrm{~cm}^{-1}$ in the case of DNA extracted from Rebra leaves, and at $1121 \mathrm{~cm}^{-1}$ for genomic DNA extracted from $\mathrm{cv}$. Florina leaf tissues.

A vibration originating mainly in the deoxyribose-phosphate appeared also in our spectra at $1159 \mathrm{~cm}^{-1}$, in the case of DNA extracted from leaves of rootstock M9. This band was detected at $1158 \mathrm{~cm}^{-1}$ for DNA from Romus 4 cultivar and near $1161 \mathrm{~cm}^{-1}$ for Idared and M26, respectively.

Besides, we have found a band centered near $1175 \mathrm{~cm}^{-1}$, in the SERS spectra of genomic DNA from Goldrush and Rebra cultivars, respectively, containing a major contribution from cytosine residues. This band shifted to $1176 \mathrm{~cm}^{-1}$ in the SERS spectrum of DNA extracted from leaves of Florina cultivar.

The SERS bands appearing in the wavenumber range $1294-1313 \mathrm{~cm}^{-1}$ for genomic DNAs from different apple leaf tissues, can be attributed to the ring vibration of adenine (see Table 2).

Besides, we suppose that the peak near $1342 \mathrm{~cm}^{-1}$ in the SERS spectra of the DNA extracted from Romus 4 leaves, arises from the ring stretching of dA [36,38]. Other authors indicate also the guanine residues as contributors to this vibration $[15,32,37]$. This band shifted to $1343 \mathrm{~cm}^{-1}$ for DNA from Idared cultivar, to $1345 \mathrm{~cm}^{-1}$ for DNA extracted from rootstock M26, to $1346 \mathrm{~cm}^{-1}$ for DNA isolated from leaves of Romus 3 cultivar and to $1347 \mathrm{~cm}^{-1}$ for DNA from rootstock M9.

The high intensity peak near $1358 \mathrm{~cm}^{-1}$ in the SERS spectrum of DNA from Florina cultivar is mostly due to the $\mathrm{dT}$ and $\mathrm{dA}$ residues. This band was found at $1364 \mathrm{~cm}^{-1}$, in the case of DNA extracted from cv. Rebra and at $1365 \mathrm{~cm}^{-1}$, in the case of DNA purified from Goldrush cultivar. 
The SERS band near $1404 \mathrm{~cm}^{-1}$, attributed to DNA extracted from cv. Romus 3 leaves, is due to vibrations localized in the thymine, adenine and guanine rings [32].

A weak band was detected previously by us around $1423 \mathrm{~cm}^{-1}$ in the SERS spectrum of genomic DNA extracted from leaves of in vitro-grown Rebra cultivar [20]. This band indicated vibrations of the $\mathrm{d}\left(2^{\prime}-\mathrm{CH}_{2} \delta\right)$ and $\mathrm{dA}$ molecular subgroups and is absent in the present data set.

The shoulder at $1446 \mathrm{~cm}^{-1}$ in the SERS spectrum of genomic DNA extracted from Romus 3 leaves is attributed to the $\mathrm{CH}_{2}$ scissor of deoxyribose [19,28,34,35,37]. This band was detected near $1451 \mathrm{~cm}^{-1}$ in the case of DNAs from Idared and M26 leaves, respectively and around $1442 \mathrm{~cm}^{-1}$ for genomic DNA extracted from the leaf tissues of rootstock M9. Relating to these bands, Wu and coworkers [37] concluded for some oligonucleotides, that the observations of the methylene scissoring modes of deoxyribose at 1416 and $1464 \mathrm{~cm}^{-1}$, in strong to medium intensities, support the model that DNA lies flat with the backbone close to the metal surface [37].

A prominent band was found at $1510 \mathrm{~cm}^{-1}$, in the spectrum of DNA extracted from Goldrush leaves, being probably due to contributions from adenine residues [20]. It appeared as a shoulder in the SERS spectrum of DNA from Romus 4 cultivar. This band shifted to $1512 \mathrm{~cm}^{-1}$ for DNA extracted from leaf tissues of Rebra cultivar and was detected near 1500,1502, 1504 and $1506 \mathrm{~cm}^{-1}$ for DNAs extracted from leaves of M9, Idared, M26 and Florina, respectively.

The strong band near $1574 \mathrm{~cm}^{-1}$ in the SERS spectra of genomic DNA extracted from leaf tissues of Goldrush and Rebra cultivars, arises from dG and dA ring stretchings [37] and references therein. The dA vibration around this wavenumber involves a large amplitude on $\mathrm{N}^{2} \mathrm{H}_{2}$ [37] and references therein. This band was found near $1570 \mathrm{~cm}^{-1}$ for DNA extracted from cv. Florina leaves, and at $1592 \mathrm{~cm}^{-1}$ for DNA from leaf tissues of cv. Idared. Other bands found between 1545 and $1553 \mathrm{~cm}^{-1}$ for genomic DNAs extracted from leaves of different apple cultivars and rootstocks, were also attributed to dG and dA residues (see Table 2).

The carbonyl stretching vibrations of $\mathrm{dT}, \mathrm{dG}$ and $\mathrm{dC}$ are expected to be in the region of 1600 $1750 \mathrm{~cm}^{-1}$. The $\mathrm{C} 4=\mathrm{O}$ and $\mathrm{C} 2=\mathrm{O}$ of dT lead to strong peaks at 1652 and $1672 \mathrm{~cm}^{-1}, \mathrm{C} 6=\mathrm{O}$ of dG gives a moderate intensity peak at $1713 \mathrm{~cm}^{-1}$, and $\mathrm{C} 2=\mathrm{O}$ of dC near $1680 \mathrm{~cm}^{-1}$ is extremely weak in the normal Raman spectra [20,37] and references therein. We have observed a strong peak around $1647 \mathrm{~cm}^{-1}$ in the SERS spectra of DNA extracted from leaf tissues of Rebra and Florina cultivars, which might be due to $\mathrm{C}=\mathrm{O}$ stretching vibration of $\mathrm{dT}$. This band appeared at $1645 \mathrm{~cm}^{-1}$ in the SERS spectrum of DNA from Goldrush, at $1625 \mathrm{~cm}^{-1}$ for DNA from Romus 3 cultivar and was detected as a shoulder in the case of Idared $\left(1633 \mathrm{~cm}^{-1}\right)$, M9 $\left(1632 \mathrm{~cm}^{-1}\right)$, Romus $4\left(1633 \mathrm{~cm}^{-1}\right)$ and M26 $\left(1631 \mathrm{~cm}^{-1}\right)$ leaves, respectively (Fig. 1).

Many of the observed peaks show wavenumber shifts in the SERS spectrum as compared with previous normal Raman literature [32]. In a surface-enhanced Raman scattering experiment the DNA molecules may interact with the metallic substrate, resulting a wavenumber shift of the Raman band [32]. Also, intensity changes with regard to normal Raman spectra of DNA molecules can be appreciated. An example of the relative peak intensities in the normal Raman and SERS spectra of oligonucleotides is given elsewhere [37].

Some authors have found that SERS features of DNA appeared to be sequence- and/or compositiondependent [3] and references therein. SERS spectra of nucleic acids-silver colloid systems are compared here with caution, because these signals are time-dependent and are strongly influenced by DNA amount in the measured sample volume. So, the relative orientation of the molecule with respect to the metal surface, which in turn is dependent on the biopolymer concentration, is also responsible for the observed SERS signal [26]. 
Similarities of the SERS spectra of genomic DNAs extracted from leaves sampled from apple trees grown in the field, in the case of Goldrush, Rebra and Florina cultivars, respectively, have been found (Fig. 1 and Table 2). These SERS spectra show well resolved, accurate bands, providing thus a high molecular structural information content. Besides, another group of three SERS spectra, corresponding to DNA from M9, Romus 4 and M26 leaves, respectively, show similar features and well resolved bands (Fig. 1).

The present SERS data are much better as compared with our previous FT-Raman spectra obtained for DNA from different sources of leaf tissues, as far as band resolution and signal to noise ratio are concerned [19].

\section{Conclusions}

In this work, surface-enhanced Raman spectra of eight genomic DNAs from apple leaves sampled from trees grown in the field (Malus domestica Borkh., Fam. Rosaceae, cvs. Florina, Idared, Rebra, Goldrush, Romus 3, Romus 4 and the rootstocks M9 and M26) were recorded and discussed, respectively, in the $200-1800 \mathrm{~cm}^{-1}$ spectral range.

A detailed comparative analysis of the SERS signatures of genomic DNAs extracted from apple leaves is given. SERS wavenumbers $\left(\mathrm{cm}^{-1}\right)$ are reported here for all types of vibrations of plant genomic DNAs, including bands assigned to localized vibrations of the purine and pyrimidine residues, localized vibrations of the deoxyribose-phosphate moiety, etc. [6,19]. Proposed SERS band assignments found in the literature for similar compounds were given.

Strong time dependence of the SERS spectra, and dependences on genomic DNA amount in the sample volume have been found. That is why SERS spectra of nucleic acids are compared here with caution.

Bands near $689 \mathrm{~cm}^{-1}(\mathrm{dG}), 729 \mathrm{~cm}^{-1}(\mathrm{dA}), 752 \mathrm{~cm}^{-1}(\mathrm{dT}), 771 \mathrm{~cm}^{-1}(\mathrm{dC}), 840 \mathrm{~cm}^{-1}$ [ $\nu(\mathrm{O}-\mathrm{P}-\mathrm{O})$, B-type], $904 \mathrm{~cm}^{-1}$ (deoxyribose), $927 \mathrm{~cm}^{-1}$ (deoxyribose), $1005 \mathrm{~cm}^{-1}$ [ $\nu_{\mathrm{C}=\mathrm{C} \text { sym }}$ (ring), deoxyribose], $1083 \mathrm{~cm}^{-1}\left(\mathrm{PO}_{2}^{-}\right.$symmetric stretch, backbone), $1124 \mathrm{~cm}^{-1}(\mathrm{dA}), 1159 \mathrm{~cm}^{-1}$ (deoxyribose-phosphate), $1175 \mathrm{~cm}^{-1}(\mathrm{dC}), 1304 \mathrm{~cm}^{-1}(\mathrm{dA}), 1342 \mathrm{~cm}^{-1}(\mathrm{dG}, \mathrm{dA}), 1358 \mathrm{~cm}^{-1}$ (dT, dA), $1404 \mathrm{~cm}^{-1}$ (dT, dA, dG), $1451 \mathrm{~cm}^{-1}$ (deoxyribose, $\left.\mathrm{dCH}_{2}\right), 1510 \mathrm{~cm}^{-1}(\mathrm{dA}), 1574 \mathrm{~cm}^{-1}(\mathrm{dG}, \mathrm{dA})$ and $1647 \mathrm{~cm}^{-1}$ [dT(C=O), $\delta\left(\mathrm{H}_{2} \mathrm{O}\right)$ ], characteristic to genomic DNAs from different leaf tissues, sampled from trees grown in the field, are presented in detail.

In the case of Goldrush, Rebra and Florina cultivars, respectively, similarities of the SERS spectra of genomic DNAs extracted from leaves of apple trees, have been found. Besides, the SERS spectra, corresponding to DNA from M9, Romus 4 and M26, leaves, respectively, show similar features and well resolved bands.

The SERS technique-based data presented here will contribute to the rapidly growing field of nanometrology and bioanalysis using silver nanoparticles [31].

Once spectra-structure correlations in the SERS spectra of apple leaf DNAs being established in our work, future SERS experiments on plant DNA can be carried out to analyze specific genomic DNAligand interactions.

Besides, applications of plant DNA vibrational markers in forensic botany might be anticipated.

\section{Acknowledgements}

Thanks are due to Dr. Valentina Isac from Research Institute for Fruit Growing, Mărăcineni, Romania, for providing the plant material used in this study. The authors wish to thank to Mr. Mircea D. Puia, 
Babeş-Bolyai University, for the FT-Raman spectroscopic measurements of DNAs from leaf tissues (data not shown). Financial support from CNCSIS-UEFISCDI Romania, project number PNII-IDEI 519/2009, code 875/2008 is gratefully acknowledged by two of us (C.M.M. and N.L.).

\section{References}

[1] J. Anastassopoulou and T. Theophanides, Aquation of metal ions and infrared and Raman spectra of metal complexes and their interaction with DNA components, in: Insights into Vibrational Spectroscopy of Nucleic Acids and Their Complexes, C.M. Muntean and I. Bratu, eds, Transworld Research Network Publishers, Trivandrum, Kerala, India, 2009, pp. 47-65.

[2] A. Barhoumi, D. Zhang and N.J. Halas, Correlation of molecular orientation and packing density in a dsDNA selfassembled monolayer observable with surface-enhanced Raman spectroscopy, J. Amer. Chem. Soc. 130 (2008), 1404014041.

[3] A. Barhoumi, D. Zhang, F. Tam and N.J. Halas, Surface-enhanced Raman spectroscopy of DNA, J. Amer. Chem. Soc. 130 (2008), 5523-5529.

[4] C.S. Braun, G.S. Jas, S. Choosakoonkriang, G.S. Koe, J.G. Smith and C.R. Middaugh, The structure of DNA within cationic/DNA complexes, Biophys. J. 84 (2003), 1114-1123.

[5] J. De Gelder, K. De Gussem, P. Vandenabeele and L. Moens, Reference database of Raman spectra of biological molecules, J. Raman Spectrosc. 38 (2007), 1133-1147.

[6] H. Deng, V.A. Bloomfield, J.M. Benevides and G.J. Thomas Jr., Dependence of the Raman signature of genomic $B$-DNA on nucleotide base sequence, Biopolymers 50 (1999), 656-666.

[7] L. Dostal, R. Misselwitz and H. Welfle, Arc repressor-operator DNA interactions and contribution of Phe10 to binding specificity, Biochemistry 44 (2005), 8387-8396.

[8] J. Doyle and J.L. Doyle, A rapid DNA isolation procedure for small quantities of fresh leaf tissue, Phytochem. Bull. 19 (1987), 11-15.

[9] J.G. Duguid, V.A. Bloomfield, J.M. Benevides and G.J. Thomas Jr., Raman spectroscopy of DNA-metal complexes. I. Interactions and conformational effects of the divalent cations: $\mathrm{Mg}, \mathrm{Ca}, \mathrm{Sr}, \mathrm{Ba}, \mathrm{Mn}, \mathrm{Co}, \mathrm{Ni}, \mathrm{Cu}, \mathrm{Pd}$, and Cd, Biophys. J. 65 (1993), 1916-1928.

[10] J.G. Duguid, V.A. Bloomfield, J.M. Benevides and G.J. Thomas Jr., DNA melting investigated by differential scanning calorimetry and Raman spectroscopy, Biophys. J. 71 (1996), 3350-3360.

[11] D. Graham and K. Faulds, Quantitative SERRS for DNA sequence analysis, Chem. Soc. Rev. 37 (2008), 1042-1051.

[12] D. Graham, B.J. Mallinder and W.E. Smith, Detection and identification of labeled DNA by surface enhanced resonance Raman scattering, Biopolymers (Biospectroscopy) 57 (2000), 85-91.

[13] Y. Guan, C.J. Wurrey and G.J. Thomas Jr., Vibrational analysis of nucleic acids. I. The phosphodiester group in dimethyl phosphate model compounds: $\left(\mathrm{CH}_{3} \mathrm{O}\right)_{2} \mathrm{PO}_{2}{ }^{-},\left(\mathrm{CD}_{3} \mathrm{O}\right)_{2} \mathrm{PO}_{2}{ }^{-}$, and $\left({ }^{13} \mathrm{CH}_{3} \mathrm{O}\right)_{2} \mathrm{PO}_{2}{ }^{-}$, Biophys. J. 66 (1994), 225-235.

[14] M.H. Harpster, H. Zhang, A.K. Sankara-Warrier, B.H. Ray, T.R. Ward, J.P. Kollmar, K.T., Carron, J.O. Mecham, R.C. Corcoran, W.C. Wilson and P.A. Johnson, SERS detection of indirect viral DNA capture using colloidal gold and methylene blue as a Raman label, Biosens. Bioelectron. 25 (2009), 674-681.

[15] W. Ke, D. Zhou, J. Wu and K. Ji, Surface-enhanced Raman spectra of calf thymus DNA adsorbed on concentrated silver colloid, Appl. Spectrosc. 59 (2005), 418-423.

[16] J. Kneipp, B. Wittig, H. Bohr and K. Kneipp, Surface-enhanced Raman scattering: a new optical probe in molecular biophysics and biomedicine, Theor. Chem. Acc. 125 (2010), 319-327.

[17] N. Leopold and B. Lendl, A new method for fast preparation of highly surface-enhanced Raman scattering (SERS) active silver colloids at room temperature by reduction of silver nitrate with hydroxylamine hydrochloride, J. Phys. Chem. B 107 (2003), 5723-5727.

[18] C.M. Muntean, L. Dostál, R. Misselwitz and H. Welfle, DNA structure at low pH values, in the presence of $\mathrm{Mn}^{2+}$ ions: a Raman study, J. Raman Spectrosc. 36 (2005), 1047-1051.

[19] C.M. Muntean, A. Halmagyi, M.D. Puia and I. Pavel, FT-Raman signatures of genomic DNA from plant tissues, Spectrosc. Int. J. 23 (2009), 59-70.

[20] C.M. Muntean, N. Leopold, A. Halmagyi and S. Valimareanu, Surface-enhanced Raman spectroscopy of DNA from leaves of in vitro-grown apple plants, J. Raman Spectrosc. (2010), doi: 10.1002/jrs.2780.

[21] C.M. Muntean, R. Misselwitz, L. Dostál and H. Welfle, $\mathrm{Mn}^{2+}$-DNA interactions in aqueous systems: a Raman spectroscopic study, Spectrosc. Int. J. 20 (2006), 29-35.

[22] C.M. Muntean, K. Nalpantidis, I. Feldmann and V. Deckert, $\mathrm{Zn}^{2+}$-DNA interactions in aqueous systems: a Raman spectroscopic study, Spectrosc. Int. J. 23 (2009), 155-163. 
[23] C.M. Muntean, G.J. Puppels, J. Greve and G.M.J. Segers-Nolten, The influence of $\mathrm{Ca}^{2+}$ cations on the low pH-induced DNA structural transitions, Biopolymers (Biospectroscopy) 67 (2002), 282-284.

[24] C.M. Muntean, G.J. Puppels, J. Greve, G.M.J. Segers-Nolten and S. Cinta-Pinzaru, Raman microspectroscopic study on low pH-induced DNA structural transitions, in the presence of magnesium ions, J. Raman Spectrosc. 33 (2002), 784-788.

[25] J.F. Neault, M. Naoui, M. Manfait and H.A. Tajmir-Riahi, Aspirin-DNA interaction studied by FTIR and laser Raman difference spectroscopy, FEBS Lett. 382 (1996), 26-30.

[26] C.V. Pagba, S.M. Lane and S. Wachsmann-Hogiu, Raman and surface-enhanced Raman spectroscopic studies of the 15-mer DNA thrombin-binding aptamer, J. Raman Spectrosc. 41 (2010), 241-247.

[27] G.J. Puppels, C. Otto, J. Greve, M. Robert-Nicoud, D.J. Arndt-Jovin and T.M. Jovin, Raman microspectroscopic study of low pH induced changes in DNA-structure of polytene chromosomes, Biochemistry 33 (1994), 3386-3395.

[28] A.J. Ruiz-Chica, M.A. Medina, F. Sanchez-Jimenez and F.J. Ramirez, On the interpretation of Raman spectra of 1-aminooxy-spermine/DNA complexes, Nucleic Acids Res. 32 (2004), 579-589.

[29] W. Saenger, Principles of Nucleic Acid Structure, C.R. Cantor, ed., Springer-Verlag, New York, 1984.

[30] G.M.J. Segers-Nolten, N.M. Sijtsema and C. Otto, Evidence for Hoogsteen GC base pairs in the proton-induced transition from right-handed to left-handed poly(dG-dC) $\times$ poly(dG-dC), Biochemistry 36 (1997), 13241-13247.

[31] R.J. Stokes, A. Macaskill, P.J. Lundahl, W.E. Smith, K. Faulds and D. Graham, Quantitative enhanced Raman scattering of labeled DNA from gold and silver nanoparticles, Small 3 (2007), 1593-1601.

[32] L. Sun, Y. Song, L. Wang, C. Guo, Y. Sun, Z. Liu and Z. Li, Ethanol-induced formation of silver nanoparticle aggregates for highly active SERS substrates and application in DNA detection, J. Phys. Chem. C 112 (2008), 1415-1422.

[33] G.J. Thomas Jr., J.M. Benevides, J. Duguid and V.A. Bloomfield, Roles of cations in the structure, stability and condensation of DNA in: Fifth International Conference on the Spectroscopy of Biological Molecules, T. Theophanides, J. Anastassopoulou and N. Fotopoulos, eds, Kluwer Academic Publishers, Dordrecht, 1993, pp. 39-45.

[34] G.J. Thomas Jr., J.M. Benevides, S.A. Overman, T. Ueda, K. Ushizawa, M. Saitoh and M. Tsuboi, Polarized Raman spectra of oriented fibers of $A$ DNA and $B$ DNA: anisotropic and isotropic local Raman tensors of base and backbone vibrations Biophys. J. 68 (1995), 1073-1088.

[35] M. Tsuboi, J.M. Benevides and G.J. Thomas Jr., The complex of ethidium bromide with genomic DNA: structure analysis by polarized Raman spectroscopy, Biophys. J. 92 (2007), 928-934.

[36] K.A. Willets, Surface-enhanced Raman scattering (SERS) for probing internal cellular structure and dynamics, Anal. Bioanal. Chem. 394 (2009), 85-94.

[37] C.-Y. Wu, W.-Y. Lo, C.-R. Chiu and T.-S. Yang, Surface enhanced Raman spectra of oligonucleotides induced by spermine, J. Raman Spectrosc. 37 (2006), 799-807.

[38] W. Xie, Y. Ye, A. Shen, L. Zhou, Z. Lou, X. Wang and J. Hu, Evaluation of DNA-targeted anti-cancer drugs by Raman spectroscopy, Vib. Spectrosc. 47 (2008), 119-123. 


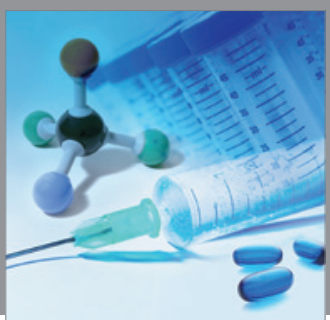

International Journal of

Medicinal Chemistry

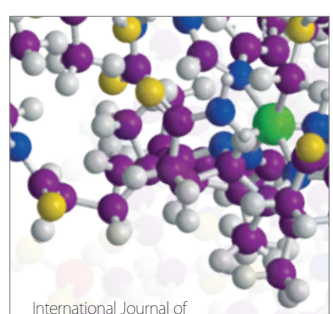

Carbohydrate Chemistry

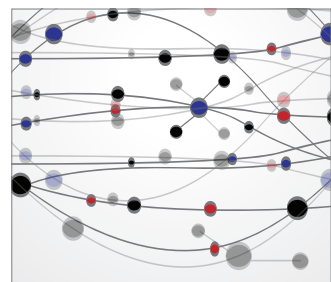

The Scientific World Journal
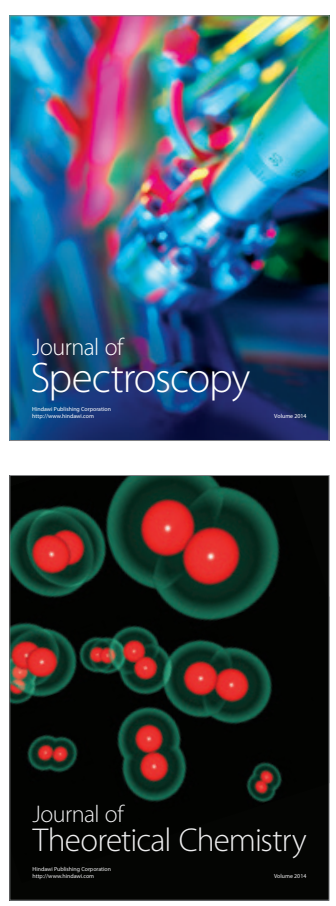
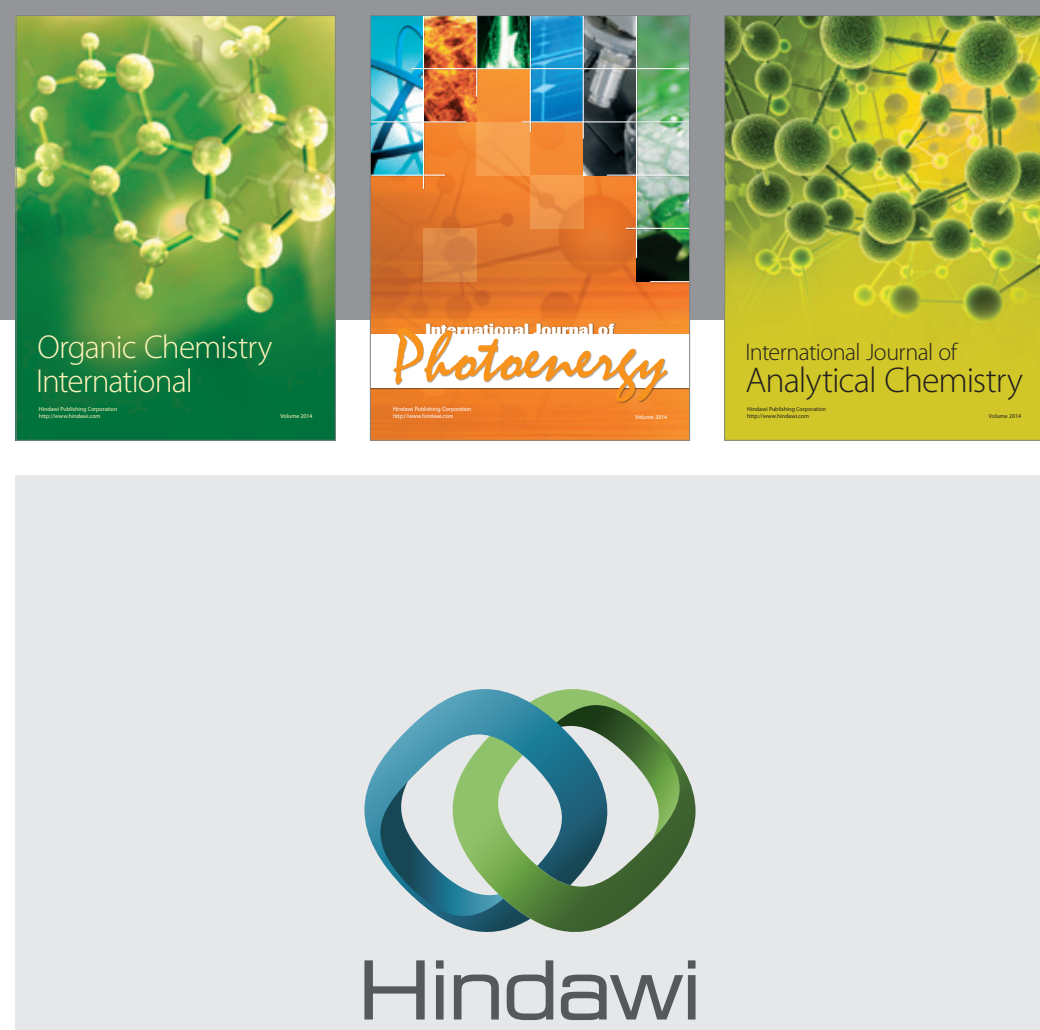

Submit your manuscripts at

http://www.hindawi.com
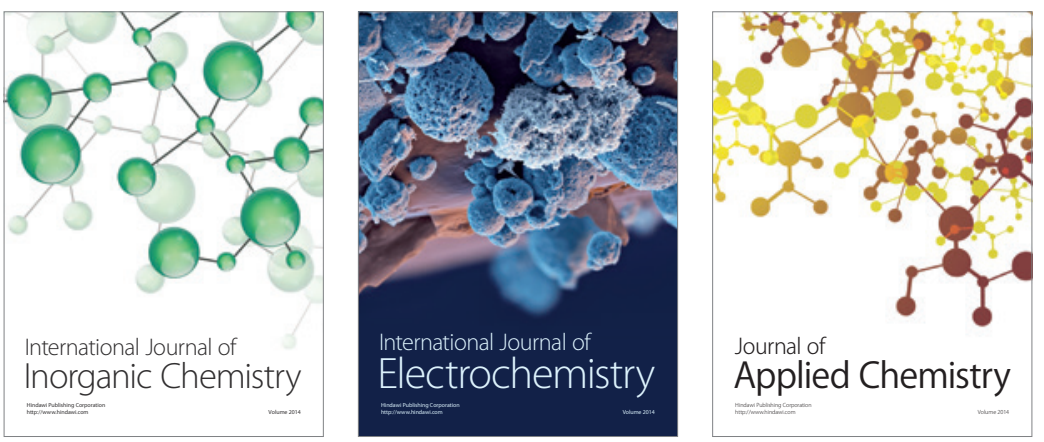

Journal of

Applied Chemistry
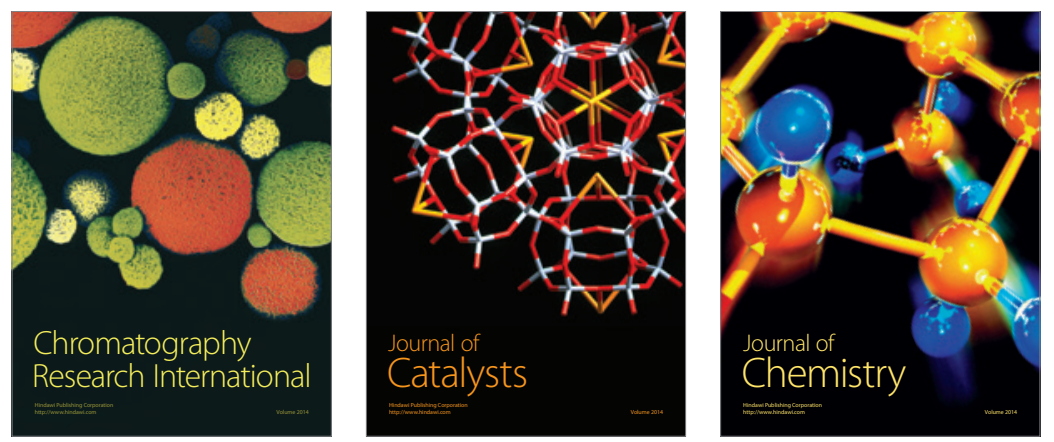
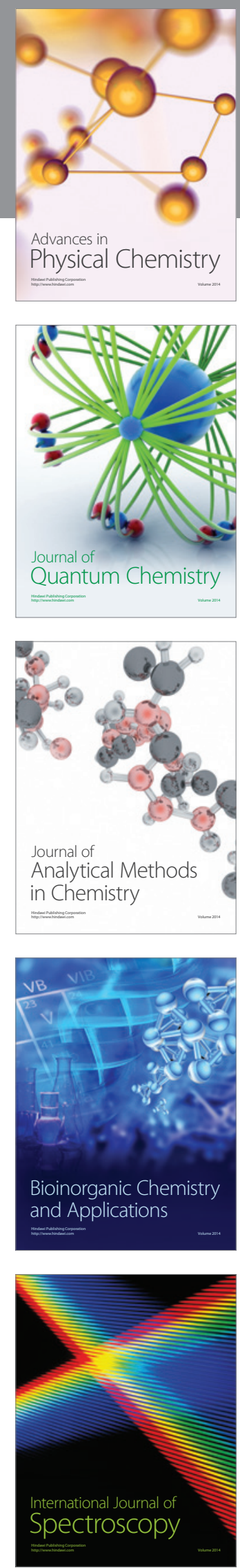